\title{
6. THE HEALING POWER OF ART-THERAPY
}

Felicia Ceaușu ${ }^{236}$

\begin{abstract}
In Europe, since the middle of the $19^{\text {th }}$ century, physicians realized that by plastic creation an improvement of the mental state of many patients can be achieved. Painting, household chores or gardening were meant to eliminate boredom and to take the patients out of isolation. Various activities of today's art-therapy. At the beginning of the $20^{\text {th }}$ century, various authors showed interest for the paintings and drawings of mental patients. The interest attracted by the psycho-pathological art allowed the organization of international exhibits with the artistic works of the mental patients. The scientific approach of these ways of pathoplastic expression determined the emergence of institutions, studies, periodicals and international reunions concerning this topic.
\end{abstract}

Keys words: art-therapy, personality, plastic expression, rehabilitation

\section{Introduction}

Art may heal various pathological states. This idea is very old and was applied since Antiquity. "Major figures of those times like Plato, Aristotle, Plutarch, Pythagoras recommended for therapeutic purposes the contemplation of art works." ${ }^{237}$ When looking at an art work you feel obliged to focus on it, you forget about the problems bothering you. In China and Japan the virtues of art were used to treat precarious psychological states. This therapy stimulated the process of getting healthier. "For healing physical and mainly psychic states, the patients were recommended to pain or draw in nature. It was also a therapy through color." 238

In recent times, medical research strengthened the conclusion that the therapeutic virtues of the art are related to the type and topic of the works, to the intellectual training and to the patient's sickness. In case of chronic melancholies and severe depressions, the use of therapy through colors started to be broadly applied in the US, Japan, China, ex-USSR, France etc. Research showed that not any work of art had a positive impact on health. Some works by their chromatics and topic have an unsettling effect and, therefore, must be avoided in the therapy of patients.

In Leningrad, the therapy through art was used to treat diseases of internal organs: hepatic, gastric and pancreatic diseases as the sick were put in front of some works creating a very favorable psychic state and thus increasing the efficiency of some drugs. The therapeutic sessions of looking at some famous art works made by brilliant painters and sculptors such as: Delacroix, Goya, Rodin, Braque were short but these were repeated for 5-10 times a day by projection on color devices or by visits to museums. The results of this experiment were sensational.

\footnotetext{
${ }^{236}$ Researcher PhD., Romanian Academy, Institute "Gheorghe Zane" from Iași Branch, Romania, email: ceausufelicia@yahoo.com

237 J. Rodriguez and G. Troll, L'art therapie. Pratiques, techniques et concepts, Ellebore, Paris, 2001, p. 265

${ }^{238}$ Forestier R., Tout savoir sur l'art therapie, Favre, Laussane, 2000, p. 73
} 
The changing of the psychic state of the patient, the elimination of stress and the beneficial effect of colors, all of these improved the healing of some organic and functional diseases in a faster way compared to the usual therapies. We have to underline that when this is abused and the brain gets tired by many viewings, hearing and sight disturbances may occur as well as hallucinations, angst or disorders of the heart rhythm. Some patients may experience the "Stendhal syndrome" discovered by the famous author. This syndrome occurs many times in tourists who, in a very short time, look at the famous art collections of museums sitting for hours and hours and getting tired, experiencing stress states, physical and psychic fatigue. It begins with anxiety, a state of relentless panic and then a form of uncontrollable euphoria can be triggered. "The art-therapy has a broad applicability as it is used mainly for the rehabilitation, stimulation and development of children and adults with physical and mental disabilities but also for personal development and in education, respectively in prevention."239

The working models practiced in Romania starting from the 90s, together with the information transfer especially in practice, made by various charity NGOs, are homologated and come from the UK, France and Germany, countries with a tradition in the research / development of art-therapy and related techniques. Visual arts, music, literature, physical exercises, dancing, theater and puppet shows are the main components of these techniques. In Romania, the specialists and the NGOs they represented opted for a plan with long-term effects, with an incidence at national level with the aim of helping as many beneficiaries as possible. After 1990, the Romanian movement of art-therapy grew and development of several levels of professionalization. Gradually, a critical mass of professionals was created who work in various rehabilitation centers and local NGOs from all over the country and who have the same source of initial training. Positive results soon followed as well as the desire of the coordinators and the authorities to extend this successful model.

The initiative to professionalize the profession of art-therapist by organizing master studies represents a normal step in developing the field of arttherapy in Romania and represents the legitimate desire of many groups directly involved in the daily activities with the beneficiaries of the social system of protection or care in Romania. Many of the persons already working with techniques specific to art-therapy have a university education in the artistic and/or psychic-social fields. The official recognition of the profession of arttherapist, after graduating master studies, offers knowledge and develops new skills and professional abilities and helps the students to be competitive in a continuous growing market.

By using the expression means specific to art in the activity of professional in the field of human psycho-somatic-social development, it was found out that one of the basic needs of people is to express what they feel. Art, like any other technique used for artistic expression, cannot be separated from

${ }^{239}$ Preda, Vasile, Terapii prin mediere artistică, Editura Presa universitară clujeană, Cluj-Napoca 2003, p.122 
emotions. When we refer to the emotional level of humans, we must consider therapy. "At the emotional level of the artistic creator, we find the same ingredients necessary for psychotherapy. Each individual has his/her own perceptions and emotions, with his his/her cultural influences. The sensations originate within the setting of our social-cultural condition. As they are present in a relational framework, these become the result of projections." ${ }^{240}$ At this moment, the therapy through art becomes essential since it allows the experience of some positive and valorizing emotions and leads to the balance of the normal cycle of contraction - expansion which is characteristic to the human being.

\section{The benefits of art-therapy}

Art-therapy, through the access to the nature of self-transformations and the relationship between humans, by its positive values which are the basis of understanding, exploration and assistance to the human being is a way of regaining and maintaining the somatic-psycho-social health as well as a way to prevent alienation. Art-therapy offers to the beneficiary that safety that is much needed and that freedom of manifestation and expression of desires, opinions, own attitudes and satisfies the human needs of belonging and identification with a group.

The neuropsychology of drawings defines it as a complex process of personality expression with a cortical representation and with the same value as spoken language (oral and written) in relation with the symbolic gnosticpraxeological cortical functions. The psychological foundation for explaining the neuropsychological nature of drawings refers to:

- The drawing as an instrumental symbolic function of the brain with the same value as the spoken language

- The drawing as a representation at the level of certain cortical areas

- Any lesion generated at the level of the cortical areas of the drawing will determine a disturbance specific to drawings

- As a neuropsychic function, the drawing may be considered as a form of psycho-diagnostic analysis.

In the category of the most frequent disorders that are plastically expressed with a diagnostic value, we mention ${ }^{241}$ :

1. Disturbances related to shape that represent modifications of the shape without essentially changing the natural shape

2. Disturbances related to the execution of the shape determining a rigid, poor, messy and undetermined appearance

3. Disturbances related to the construction of the shape consisting of:

- Emphasis on a non-essential element

- Shape stereotypy

- Omission of some essential elements

- The color does not support the shape.

\footnotetext{
${ }^{240}$ Fabini, Dana, Creativitate artistică. Relaţii între artele vizuale şi terapia prin artă, Presa Universitară Clujeană, Cluj-Napoca, 2006, pp. 54-55

${ }^{241}$ Popescu Al., Terapia ocupaţională şi ergoterapia, Edit. Medicală, Bucureşti, 1986, p.67
} 
4. Disturbances of body schematics referring to:

- Body transparency

- Pronounced asymmetries, disproportionalities between the various sections of the body

- Omissions or additions of section

- The body rendered "from the front and the head and legs "from the side"

- Asymmetric, deformed head that not connected to the neck and with an open outline (upwards)

- Limbs with an appendicular and asymmetric appearance, over- or undersized limbs, uni- or bilateral absence

- "New formation" = two heads, three hands, more fingers.

5 . Disturbances of the symbolic meaning of the shape - they occur when the student's imagination is put to work and he/she is not able to create or use the "symbol shape" and refers to:

- The color covering in an illogical way all the elements (e.g. the head has the color of the clothes)

- Special drawing techniques (shades, color spots) that have no meaning and significance.

6. Disturbances of compositions. The composition is the most complex activity of drawing concurring with many factors, with logical compositional principles; these factors confer rhythm, balance, measure, proportions, emotional and communication force to the plastic composition. Its disturbances refer to:

- The absence of relations between shapes, details, space

- An "in plane" close composition that is rendered frontally in two dimensions with a static appearance

- Frequent repetition of "schematic" shape

- The affective perspective dominates the visual perspective by reversing the real ratios between the elements

- Failure to give attention to the "environment" characteristic to the topic

- The color has not constructive or impressive role but expresses only the internal feelings of the child

- Narrow perceptive plane offering poor, lacunar, unreal and dismembered images

7. Disturbances of color. The entire harmony of a plastic work is supported by the dominant chromatic tonality, on a balance that is subjectively directed. The disturbances refer to:

- Failure to observe visual realism

- Absence of a refined chromatic harmony, tones or nuances

- Illogical use of colors (red snow, green hair)

- The spatial effect of colors is not used and the drawing is flat in two dimensions with a messy appearance.

8. Disturbances of the plastic space (relating the composition structure with its shape as a whole). The disturbances refer to ${ }^{242}$ :

${ }^{242}$ Williams G.H., Wood M., Developmental Art Therapy, Baltimore University Park Press, 1977, p.90 
- Open, empty, poor, simplistic, static, raw and gloomy space

- Descriptive, serial, decorative

- Unbalanced space by under- or oversizing the shapes.

The drawing is a complex mechanism driving many sides of the psychology of the individual with a strictly individual specific character in relation with the particularities of the respective subject, with his/her ability of expression, with his/her skills and cultural level, with his/her affectivity and the entire dynamics of his/her personality.

\section{Interpretation of drawings to people with mental disorders}

The interpretation of drawings highlights several points of view oriented towards two directions: the esthetic and the psychological one as these are legitimate together since the drawing before being "a work" is "a language", a symbolic neuropsychological information system. The psychological direction that is our focus is the one depending on the structure and the dynamics of personality. The drawing acts as a vehicle for the intra-psychic content of the individual, reflecting his/her general personality.

The drawing, in the case of persons with psychic disorders, appears as and "accessible language operating as a specific system" ${ }^{243}$ of concrete physical signs through which it develops a "circulating-communicable" form within interpersonal communication, behaving as the value of a message expressing outwards the global intra-psychic content of the personality of the deficient. Therefore, the drawing as language and message is the carrier of information which the subject sends, with a certain meaning and in a specific physical form that is particular to this type of language (graphical-plastic sign). In other words, the drawing, as a plastic message, has an accurate semantic system, an information code that, within interpersonal communication, will be subject to the general laws of semantics. Plastic expression, the drawing, within the setting of investigations on the deficient exceeds the points through which they are seen as practical abilities to copy reality and their features refer to ${ }^{244}$ :

- Expressive value - given by the graphic gesture translating some aspects related to temperament and the nature of the tonic-emotional reactions of the subject

- Projective value - refers to the ability of the drawing to give a faithful image of the personality of the subject (= intra-psychic content)

- Narrative value - it is the value that sensitizes and draws attention as it is influenced by the search of what is of interest for the subject, by the selection of the drawing's topics, all of these in relation with personal experience, memories, personal imagination

- Associative value - through which the drawing is the result of a cluster of meanings and, in this way, the content of the drawing (topic, style) is closer to a dream as a type of psychological elaboration.

\footnotetext{
${ }^{243}$ Kramer E., Childhood and art therapy, Schooken Books, 1978, USA, p.145

${ }^{244}$ Enăchescu C., Igiena mintală şi recuperarea bolnavilor psihici, Edit. Medicală, Bucureşti, 1979, p.78
} 
Since the period of symbolic play, the child exercises his/her symbolization functions, modeling, drawing, all being ways of a bipolar communication act with his/her own being and with those outside. "The symbolic play is always a mixture of action and dream, it achieves the dream by action, and it idealizes the action through dream. The play has a progression on things and evades things. It takes over the world and creates another world. That's the reason why some tried to explain art through play."245

On one hand, it is said that the artistic impulse has its roots in the subconscious activity of the child who plays in his/her captivating struggle to form him/herself, in his/her simultaneous and contradictory desire to impose on the attention of people and to isolate him/herself in order to taste the whole seduction of the play. James Sully, Popa M. (1997). On the other hand, it is said that the primitive art, mostly through the representation of fights and hunting scenes, seems to prove that art is only a continuation of the activity of play.

However, it is proved that art does not come from play but rather from all human activities. "Art is one of the ways in which the entire activity of humans is used and consumed"246. Dancing is not a simple game, a simple expression of movement from an excess of used energy, it mixes up with the useful and mystic aims of collective life and involves moods that are extremely profound and complex, without giving up to all that the art itself adds to these primitive forms, without giving up to the purely esthetic forms of the self.

From a psychological point of view, there are many similarities as well as differences between play and art - the play is liberation - same as the art, it unshackles, liberates someone from reality. Same as art, it is the creation of some profound tendencies. Its message is freedom through action and through dream. However, in arts, we are not talking about a play of images and feelings, we are talking about a selection of images and feelings which are expressive and beautiful and are able to order themselves in harmonious symbols.

Art builds a world imposing on the spirits by order and its laws. Art does not mean that monotonous and fugitive creation which loses itself in ephemeral emanations and which remains transcendental and insensitive to the structure and external appearance of its accomplishments. The play contributes to the preparation of art but the play becomes art only for the being that is on the highest edge of spirituality. The play becomes art when the one who is playing is an artist. Kramer, E. (1978) Edith Kramer in her work - Childhood and art therapy (1978) considers "some types of play as a preparation for the arts." In this regard she shows that - "small children need to play with soft and unstructured materials such as water, sand, clay, stones, glue.”247

\section{The mechanisms of art-therapy}

Based on the understanding of the child's psychology, Freud's theory, E. Kramer underpins the idea of art as a purpose. Art-therapy has the force to

\footnotetext{
${ }^{245}$ Enăchescu C., Expresia plastică a personalităţii, Edit. Ştiinţifică, Bucureşti, 1995

${ }^{246}$ Delacroix H., Psihologia artelor, Edit. MERIDIANE, Bucureşti, 1983

${ }^{247}$ Kramer E., Childhood and art therapy, Schooken Books, USA, 1978
} 
sustain the Ego, to amplify the development of the meaning to facilitate the psychic organization of the individual so that he/she to be able to function in stress conditions without damage. In this way, art-therapy becomes both a component of a therapeutic environment (together with other types of therapies) and a form of complementary therapy or supporting psychotherapy without replacing it. The features of the pathoplastic art:

\section{In oligophrenia:}

- It has an infantile, simple, naïve, schematic appearance; it renders the nonessential life aspects, construction defects of images.

\section{In neuroses:}

- Creation has an unequal, disharmonic appearance with inconsistencies, comebacks or abandonment, bizarre topics as choosing and way of treatment.

\section{In schizophrenia:}

- It has a bizarre, unusual appearance, rigid construction, tendency to stylization-geometrization, of filling up the space, cold chromatics, presence of symbols.

\section{In manic-depressive psychosis:}

- The character is given by the periodical alternation of the two maniacal or melancholic phases.

- The maniacal artistic creation: it is characterized by joyful, expansive, cheerful topics, predominance of warm tones.

- The melancholic artistic creation: in this phase, the interest for drawing/painting is reduced; the topics are grim, sad, monothematic, poor, cold chromatics, monochromatic, poor, clumsy composition.

\section{In epilepsy:}

- The paroxysmal and inter-paroxysmal creation, the latter was studied more; we can see a tendency towards rendering the details by points, lines repeated at very short intervals.

Edith Kramer (1978) distinguishes five ways in which the materials specific to arts can be used. The first four are not considered art and are explained as being preliminary stages, dysfunction symptoms which reflect a psychological disorder or a limited communication. The first category consists of - preliminary activities, activities of exploring the physical properties of materials which are not involved in the creation of symbolic configurations but are considered positive. The second category is described as being chaotic activities - such as smudging, splashing, doodling - destructive components determined the losing control. The third category - stereotypes - denoted as actions for defense. These can take the form of copying, plotting or stereotypic repetitions. Two types comprise this category:

a. Conventional stereotypes;

$b$. Rigid or bizarre stereotypes that have a personal meaning, highlighting false fillings.

The fourth category and the most controversial is pictography which represents a pictorial communication replacing or supplementing words. The fifth category, the one of - formal expression - defines the creation of symbolic 
configurations successfully serving both to the expression itself and to communication. For E. Kramer, only this way of using materials represents art in the deep meaning of the word since it derives from evoked feelings and serves as an analogue for a varied form of human experiences.

The categories highlighted by Kramer not rigidly separated so that a child can pass through preliminary activities of play to formal expression, he/she can regress to chaotic creations, he/she can abandon a depressive activity and can come back to a creative, final activity. The aim of the art-therapist is to help people, children or adults, to create works that are at the same time expressive and formal as there are periods when creative activity goes beyond the daily reality and when these ways to exist, to function are more useful for the individual. Therapy through art is related to the concept of sublimation, to the pleasure experienced by the subject by sublimation. "In art, sublimation is obtained when the artist replaces his/her impulse to exteriorize fantasies with the act of creating equivalent elements for his/her fantasies by visual images. These creations become art only when the artist manages to make them intelligible to others in order to communicate." 248 The role of the art-therapist is to distinguish and answer to the obvious as well as hidden aspects of the child's creations and to help him/her in creating emotionally expressive materials.

\section{The effects of art-therapy}

In art, the image is a substitute, a way to exteriorize life experiences, erotic impulses, sexual fantasies in many cases. According to Freud, the effects of art-therapy are:

1. Restating the ego;

2. Person identification;

3. Deconfliction;

4. Learning cultural symbols;

5. Affective rebalancing;

6. Affective-emotional differentiation;

7. Compensation of some altered components;

8. Self-valorization by socialization.

The objectives of art-therapy are achieved by ${ }^{249}$ : Popa M. (1997)

1. Perception of cultural symbols and facts;

2. Affective-cognitive reception of symbols;

3. Imitation and execution of symbols;

4. Their transformation in own activities;

5. Development of some forms of interest, award, motivation;

6. Selection of knowledge values and activities;

7. Providing a feeling of comfort by these activities.

Nowadays, there are a series of studies and research related to the expression forms of the normal child. They are also used as a way of

\footnotetext{
${ }^{248}$ Fabini, Dana, Creativitate artistică. Relaţii între artele vizuale şi terapia prin artă, Presa Universitară Clujeană, Cluj-Napoca, 2006, p. 54

${ }^{249}$ POPA M., - Note de curs de Ergoterapie şi Artteapie - Dactilo, Universitatea Bucureşti, 1997
} 
interpreting pathological or morbid personalities in deficient children or subjects with psychic disorders. The acting mechanisms of drawing in psychotherapy and rehabilitation of personality:

1. The free plastic expression representing the morbid intra-psychic content of the general personality and through which the patient can be directly contacted;

2. The symbolic content of the plastic language which is the key to the interpretation of the morbid transformation of the subject's personality;

3. The activity of plastic creation liberates the intra-psychic tension of the person and the most important are sublimation and catharsis;

4. Creation can lead to a dialogue with its author, leading to the awareness of some conflicting feelings;

5. The art develops positive reactions and removes morbid isolation

6. Helps in the discovery of (new) strategies and solutions to cope with traumatic symptoms and experiences, of prevention and reduction of stress.

\section{Conclusions}

Drawing, as complex form of expression, is capable not only to represent the formal structure and the content of the personality, but also implicitly to use it in a psycho-diagnostic investigation. Drawing is used for the psychodiagnostic investigation of the patient's personality, based on its expressive and projective function of exteriorizing the intra-psychic content, based on its communication and ability to represent aspects which the subject does not know, cannot or even does not want to verbalize.

\section{Bibliography}

1. Delacroix H., Psihologia artelor, Edit. MERIDIANE, București, 1983

2. Enăchescu C., Expresia plastică a personalităţii, Edit. Ştiinţifică, Bucureşti, 1995

3. Enăchescu C., Igiena mintală şi recuperarea bolnavilor psihici, Edit. Medicală, Bucureşti, 1979

4. Fabini, Dana, Creativitate artistică. Relaţii între artele vizuale şi terapia prin artă, Presa Universitară Clujeană, Cluj-Napoca, 2006

5. Forestier R., Tout savoir sur l'art therapie, Favre, Laussane, 2000

6. Kramer E., Childhood and art therapy, Schooken Books, 1978, USA

7. POPA M., - Note de curs de Ergoterapie şi Artteapie - Dactilo, Universitatea București, 1997

8. Popescu Al., Terapia ocupaţională şi ergoterapia, Edit. Medicală, Bucureşti, 1986

9. Preda, Vasile, Terapii prin mediere artistică, Editura Presa universitară clujeană, Cluj-Napoca 2003

10. Rodriguez J. and G. Troll, L'art therapie. Pratiques, techniques et concepts, Ellebore, Paris, 2001

11. Williams G.H., Wood M., Developmental Art Therapy, Baltimore University Park Press, 1977 